Јанко Рамач

Универзитет у Новом Саду

Филозофски факултет

Одсек за русинистику

ramacjanko@gmail.com
Оригиналан научни рад

примљено: 23. мај 2012

прихваћено: 1. октобар 2012

\title{
ПРИПРЕМЕ ЗА ОСНИВАЊЕ РУСИНСКОГ НАРОДНОГ ПРОСВЕТНОГ ДРУШТВА*
}

Сажетак: У раду се, на основу објављених извора и литературе, приказује пут од првих иницијатива и корака русинске интелигенције у Бачкој за покретање издавања новина и календара на језику Русина у Јужној Угарској, преко започете акције Ђуре Биндаса за оснивање русинске културно-просветне организације и укључивања у њу већег броја русинске интелигенције, по коначно оснивање на оснивачкој скупштини у Новом Саду 2. јула 1919. године Русинског народног просветног друштва, које је у периоду између два светска рата одиграло значајну улогу у културно-просветном и националном животу Русина у Краљевини СХС/Југославији.

Кључне речи: Русини у Бачкој и Срему, Русинско народно просветно друштво, Ђура Биндас, Михајло Мудри, Дионизиј Њаради.

Русини у Јужној Угарској до пропасти Аустро-Угарске 1918. године нису имали своје културно-просветне и националне организације. ${ }^{1}$ Значајан корак ка покретању културно-просветног и националног препорода Русина у Бачкој и Срему на почетку XX века представља покушај свештеника Ђуре Биндаса и адвокатског помоћника Михајла Хајнала 1913. године да покрену издавање новина и календара на језику Русина у том делу Монархије. Они су се обратили русинској интелигенцији позивајући је да се укључи у ову акцију, указујући да је неопходна свеобухватна културно-просветна акција која би допринела културно-просветном и економском напредовању Русина у овим крајевима, и да се на том плану може постићи значајније резултате једино ако се отпочне издавање новина и календара на

\footnotetext{
* Текст је настао као фазни резултат рада на пројекту Војвођански простор у контексту европске историје (број 177002) Министарства просвете и науке Републике Србије.

${ }^{1}$ Седамдесетих година XIX века у Руском Крстуру и у Куцури основане су народне читаонице, али оне нису одиграле значајнију улогу у културно-просветном и националном животу Русина.
} 
њиховом народном језику. ${ }^{2}$ Ипак, тада та добра идеја није била реализована због слабе организованости русинске интелигенције и неповољних материјалних и политичких прилика.

На Великој народној скупштини у Новом Саду 25. новембра 1918. године, када је проглашено присаједињење Војводине Краљевини Србији, Русини су имали 21 свог представника, а седницу је отворио и био је један од председавајућих Јован Храниловић, гркокатолички парох у Новом Саду. ${ }^{3}$ Тако су Русини дали свој допринос присаједињењу Војводине Краљевини СХC и стварању Краљевине СХC. Истина, неки аутори су истицали да су русински гркокатолички свештеници у Бачкој у време проглашења Краљевине СХС били против нове јужнословенске државе и за присаједињење Мађарској, али не наводе валидне доказе за такве своје тврдње. ${ }^{4}$ Због тога овде треба истаћи да су најистакнутији чланови Русинског народног просветног друштва (даље: РНПД) - русински гркокатолички свештеници Ђура Биндас, Хавријил Костељник, Михајло Мудри, Димитриј Нађ и крижевачки епископ Дионизиј Њаради још крајем XIX и на почетку XX века јасно изражавали своју русинску националну свест и указивали да Русинима у Јужној Угарској прети велика опасност од потпуне мађаризације. ${ }^{5}$

Непосредно после стварања Краљевине СХC 1918. године, Ђура Биндас, гркокатолички свештеник у Ђурђеву, схватио је да су за Русине у новоствореној држави Јужних Словена настали много повољнији услови за развој њиховог културно-просветног и националног живота и да је куцнуо час да се покрене акција започета 1913. године. Тако је он, како наводи у писму Ј. Храниловићу, потпуно сам, ни са ким се не саветујући, одлучио да окупи русинску интелигенцију с циљем да се оснује једно русинско културно-просветно друштво ${ }^{6}$, и 13. децембра 1918. године написао је и упутио апел русинској интелигенцији у Бачкој и Срему.

Биндас је одмах на почетку апела настојао да пробуди осећања русинске интелигенције и наводи да је стигао крај рата у ком су и Русини много претрпели и страдали. Али, како наводи даље, крај рата не долази са „зеленом гранчицом“ мира

\footnotetext{
${ }^{2}$ Текст апела Ђ. Биндаса и М. Хајнала упућен русинској интелигенцији 1913. г. објављен је у целини (Аноним: 81).

${ }^{3}$ Pekić, P., Povjest oslobodjenja Vojvodine, Subotica 1931, 310.

${ }^{4}$ У историографији о Русинима такве ставове износили су Владимир Биљња (Biljnja 1987: 25-27) и Никола Гаћеша (Gaćeša 1977: 299 -300), али обојица своје ставове заснивају на претпоставкама да је међу 200 делегата на скупу у Будимпешти 11-12. децембра 1918. године, на ком је захтевано да се Русини на Закарпатју присаједине Мађарској (Ванат 1990: 55-56) било и русинских свештеника из Бачке, али не наводе ни један доказ и ни једно име.

${ }^{5}$ Ђура Биндас и Д. Нађ су као студенти у писмима Володимиру Хнатјуку изражавали своју националну свест и указивали да су Русини у Бачкој изложени снажној мађаризацији, највише путем државних школа на мађарском језику (Гнатюк 1988: 147-153; Мушинка 1971: 232-239). Хавријил Костељник у својој Хроници Руског Крстура наводи да државна школа на мађарском језику врши мађаризацију Русина (Костельник 1998: 93-94). Епископ Д. Њаради, свестан да и црквено-верска литература може утицати на подстицање развоја националне свести, објављује за Русине у Јужној Угарској издања на њиховом језику: (Няради 1912; Няради 1917).

${ }^{6}$ Миз, Р., Іу ”Хронїки єдного часу” (1). Шветлосц, 3, Нови Сад 1969, 255.

7 Апел „Бачванско-сримскей рускей интелигенциї” у целини објавио је Р. Миз (Миз, Р., Гу ”Хронїки єдного часу”, 254-255).
} 
и спокоја, већ са страшном грмљавином и потресима, који руше стара преживела права, да би отпочео нови живот - препород народа. Због тога прваци сваког народа журе да слободу свог народа преокрену на његову корист и бољу будућност. Даноноћно раде, агитују, организују се, да би погодности златне слободе искористили да за свој народ изграде што бољу будућност. Због тога, сматра Биндас, ни русинска интелигенција не сме да седи прекрштених руку и да све мирно посматра и чека дроњаве остатке што ће им други из милосрђа добацити. Њему је било јасно да време неумитно лети и да нема времена за размишљање како ће то народ примити и како ће ценити рад своје интелигенције. ${ }^{8}$

Биндас је такође веома добро схватио да у Краљевини СХС Русини више нису подељени као што су били за време Аустро-Угарске, и да је, по његовим речима „нестао тај кинески зид који је делио Русине у Бачкој од браће у Срему.“ Он је покушао да увери русинску интелигенцију да ни малобројност Русина, којих је тада било у држави око 20.000 хиљада, ${ }^{9}$ не значи да не могу да се организију и да почну да раде, јер народ који до тада није имао властиту културу жедан је своје речи, свог писма. Због тога Биндас позива русинску интелигенцију да се уједини и да, раме уз раме, почне да просвећује властити народ на његовом језику, не плашећи се тешког посла. Сматрао је да се на почетку треба побринути за најважније: за школске књиге за децу, за календаре, а кад то буде могуће, треба отпочети са издавањем русинских недељних или двонедељних новина, са прикупљањем и публиковањем народних песама, обичаја итд. Биндас је предложио да се одмах, чим се створе за то услови, русинска интелигенција окупи на једном скупу где ће се о свему договорити. Изјавио је да он одмах даје у фонд за народне потребе 50 круна и молио је свакога, коме је упутио позив, да му се одазове својим мишљењем о свему. Истог дана Биндас се обратио Јовану Храниловићу и замолио га да се укључи у акцију русинске интелигенције и да помогне макар добрим саветима. ${ }^{10}$ Био је уверен да ауторитет и искуство Ј. Храниловића може много да помогне Русинима на почетку њиховог организовања у области културно-просветног живота.

Биндас се брзо уверио да његов апел није остао „глас вопијушћег у пустињи“, јер су почели да стижу одговори. Међутим, вероватно није могао ни да претпостави да ће се на његов апел први одазвати др Дионизије Њаради, тада помоћни епископ Крижевачке епархије, ${ }^{11}$ и да ће од њега добити значајну подршку.

\footnotetext{
${ }^{8}$ Из тог апела русинској интелигенцији, али и из писма које је Биндас касније добио од куцурског учитеља Емилијана Губаша, јасно се види да је међу русинским народом у Јужној Угарској и његовом интелигенцијом постојало извесно неповерење, понор, јер је народ сматрао да је интелигенција отуђена и да му је само на терет (Варга 1988а: 59).

${ }^{9}$ Према подацима пописа становништва у Краљевини СХС из 1921. године у држави је било 20.382 Русина (Биндас 1923: 130-131).

${ }^{10}$ Миз, Р., Гу ”Хронїки єдного часу” (1), 255.

11 Др Дионизиј Њаради (1874-1940) - гркокатолички свештеник, од 1914. помоћни епископ Крижевачке епархије, од 1920. године њен ординариј. Од 1922-1927. године као крижевачки епископ обављао је дужност апостолског администратора Прешовске епархије у Чехословачкој, а 1938-1939. године обављао је дужност апостолског визитатора са правом администратора гркокатоличких парохија Мукачевске епархије у Чехословачкој са седиштем у Хусту, одакле су га мађарске окупационе власти
} 
Њаради је у свом писму од 18. децембра саветовао да се све ради „мирно и опрезно“. Он је схватио да се у новој држави пред Русине поставља питање на ком језику ће се предавати русинској деци у школама. Сматрао је да је најбоље да се као наставни узме књижевни језик Русина/Украјинаца у Галицији, јер би се на тај начин овдашњи Русини чвршће везали за свој матични народ и то би била најбоља брана од ьихове масовне асимилације. За епископа је био веома важан и црквенорелигијски оквир, због тога је предложио да се упочетку у школама ангажују часне сестре Служебнице, које би подучавале децу у том језику. Епископ се сложио са Биндасом да треба издавати календар, али је био скептичан што се тиче издавања других књига, сматрајући да народ још није заволео књигу на свом језику, у што се, вероватно, и сам уверио, јер је слабо ишла продаја књига које је припремио и штампао на русинском језику. ${ }^{12}$ На крају Њаради саветује Биндасу да се чешће састаје са осталим свештеницима и да се о свему договарају, и обећао је да је спреман да помогне и да одобри све што буде требало. ${ }^{13}$ Ово писмо је сигурно дало Биндасу велику подршку и наду да ће се његови планови остварити.

Дан после Д. Њарадија Биндасу се на његов апел одазвао Михајло Поливка, директор школе у Руском Крстуру. Он је изразио своју спремност да у свему учествује и уверавао га да ће се одазвати и његове колеге учитељи, али је сматрао да са акцијом треба да се мало сачека, да се ситуација смири. ${ }^{14}$ Сасвим је разумљиво да су директор и учитељи као државни службеници били опрезни и да су сматрали да у тешким временима не треба журити са великим акцијама, него да је боље сачекати и видети како ће се ствари развијати. О својим дилемама Поливка је Биндасу више писао у свом следећем писму 25. децембра 1919. године. Наводи да је покушао да набави „више врста словенских књига“ и да их проучи, али због болести још није успео. Такође спомиње да су из Крстура покушали да набаве карпаторусинске књиге из Ужгорода, али одатле нису стигле ни ове књиге ни тристо поручених календара штампаних ћирилицом. Даље Поливка спомиње да је његов брат приредио неколико уџбеника за Русине/Украјинце на Закарпатју и да је покушао да ступи с њим у контакт, али ни то није успео због транспортних прилика. Ово писмо је указивало Биндасу да не може много да рачуна на М. Поливку, а и чињеница да поручене књиге нису стизале из Ужгорода била је јасан сигнал да Русини у Бачкој и Срему од браће у горњим крајевима не могу очекивати велику помоћ и да се све више морају ослањати на властите снаге.

Помало безнадежно писмо М. Поливке није поколебало Биндаса у његовим намерама: он је чврсто веровао да ће акција коју је покренуо пробудити русинску интелигенцију и да ће све кренути у жељеном правцу. На срећу, стизала су и друга писма која су давала наду да ће истрајан рад донети плодове. Емилијан Губаш,

1939. године спровеле у Југославију. Од 1919. укључује се у рад РНПД и помаже га и морално и материјално. Умро је у Мрзлом Пољу под неразјашњеним околностима 1940. године.

${ }^{12}$ То су кьиге: [Няради, Д.]. (1912). Правди католиикей в ьри. Жовква; Няради, Д. (1917). Книжочка для членовъ набожного союза 'Живого рожанца' въ епархіи крижеваикой. Загреб: Управа Епархіи;

${ }^{13}$ Цап, М., Прилоги за историю рускей култури у Югославиї.Шветлосц, 4/1980, Нови Сад 1980, 447.

${ }^{14}$ Варга, Д., Перии написал и злоеел руски школски кнїжки. Стодвацецрочнїца нарадзеня Михаила Поливки (1868-1988). Шветлосц, 4/1988, Нови Сад 1988, 499. 
учитељ у Куцури, одазвао се на Биндасов апел 20. децембра наводећи да је с одушевљењем примио његово писмо и да је спреман да у свему помогне. Међутим, он је имао прилично негативно мишљење о русинској интелигенцији: сматрао је да је њу тешко пробудити, „јер је озбиљно болесна од заразне болести“. ${ }^{15}$ Нажалост, није сасвим јасно шта је Губаш подразумевао под том заразном болести русинске интелигенције: да ли њену летаргичност и незаинтересованост за општенародне проблеме, њену промађарску оријентацију или нешто треће.

После првих одазива неколико појединаца Биндасу је стигло писмо од куцурске гркокатоличке општине. На седници 9. јануара 1919. године, којој је поред свештеника Владимира Сегедија, учитеља Е. Губаша и Михајла Стрибера, присуствовало око 50 чланова црквене општине, разматрана су и продискутована нека питања и донети закључци и одлуке: да се оснује фонд за издавање новина за „јужне Русине“ које би излазиле на „малоруском језику“, односно на оном на ком су излазиле и новине Нед ъля, ${ }^{16}$ и да се и школски уџбеници издају на том језику. Изабран је Месни просветни одбор на челу са Е. Губашом, који би требало да буде у вези са сличним одборима у другим русинским местима. На самој седници присутни су прикупили у фонд за издавање новина 1300 круна. ${ }^{17}$ Записник са те седнице послат је Д. Биндасу, а Е. Губаш је о свему обавестио и М. Поливку, да би се о томе обавестила и крстурска интелигенција. ${ }^{18}$

Ђура Биндас је одмах на почетку ове акције схватио да ће питање књижевног језика представљати озбиљан проблем, јер су се јављали различити ставови: епископ Д. Њаради сматрао је да би Русини требали да узму за свој књижевни језик језик Русина/Украјинаца у Галицији; Куцурани су чврсто стајали на позицији да за књижевни језик треба узети малоруски, али су они под тим подразумевали не украјински књижевни, већ карпаторусински књижевни језик који је био чудна мешавина народног говора Русина/Украјинаца у Угарској, црквенословенског и руског књижевног језика; Крстурци су на почетку указивали да питање књижевног језика није једноставно, а опредељивање између књижевног руског или украјинског, које ни интелигенција није добро познавала, све више је отварало и трећу могућност: да се за књижевни језик Русина у Краљевини СXC узме њихов народни језик. Истина, и Ђ. Биндас и М. Хајнал су још 1913. године предлагали да Русини у Јужној Угарској отпочну са издавањем својих новина и календара на свом властитом језику. Али сада, у току припрема за оснивање русинске културно-просветне организације постављање питања књижевног језика Русина у Краљевини СХC упозотравало је Биндаса да треба радити опрезно и да треба пронаћи пут да неслагања око књижевног језика не распламсају страсти да не би срушиле његове планове о културно-просветном и националном препороду Русина у држави. У предстојећим контактима са представницима русинске

\footnotetext{
${ }^{15}$ Варга, Д., Учителє-дзияцุи - ”народни предняцчи”. Шветлосц, 1/1988, Нови Сад 1988, 59.

${ }^{16}$ Нед Ћля (1898 - 1919) - недељне новине за Русине у Угарској које је у Будимпешти издавало министарство за попољопривреду на карпаторусинском језику.

${ }^{17}$ Варга, Д., Учителє-дзияции - "народни предняции,, 53.

${ }^{18}$ Варга, Д., Перши написал и злофел руски школски кнйжки. Стодвачечрочнїца нарадзеня Михаила Поливки (1868-1988). Шветлосц, 4/1988, Нови Сад 1988, 450.
} 
интелигенције из појединих места Биндас ће настојати да се постави тактички, уверавајући их да одлучивање о књижевном језику треба оставити за касније.

У писму Е. Губашу од 15. јануара 1919. године Биндас је прво потврдио да је примио записник куцурске црквене општине и похвалио је Куцуране да су се показали достојни да и даље у области културно-просветног живота буду предводница југословенских Русина. Даље спомиње да му са свих страна стижу повољни и одушевљени одговори у вези започете акције, али га ипак моли да се не жури са доношењем резолуција док се сви не договоре. Биндас је сматрао да у тренутку када Дунав више није граница која дели Русине у Бачкој и Срему, они треба да се уједине не само у области вероисповести, већ и у области националног живота. ${ }^{19}$ Знао је такође, да се питања језика не могу решавати путем писама и због тога изражава своју спремност да посети куцурску и друге русинске општине, да би се са свима договарао о питањима културно-просветног и националног живота Русина.

На жалост, следеће писмо Е. Губаша само је потврдило то, чега се Биндас највише плашио: да нико неће лако да одустане од својих ставова. Губаш у свом писму наводи да су куцурски учитељи једногласни у томе да русински народни језик није погодан за наставу у школи и да због тога уместо њега постепено треба увести „малоруски језик“, који би се учио од забавишта и онда од првог разреда. Колико су Куцурани били огорчени на последње Биндасово писмо показује и навођење Губаша да га је Шовш поцепао. Због тога је Губаш молио Биндаса да што пре дође у Куцуру да се о свему договоре. Обавештава га такође да је у Куцури већ прикупљено неколико хиљада круна, и да се планира акција прикупљања новца по систему „од куће до куће“. ${ }^{20}$ У следећем писму Губаш је обавестио Биндаса да је куцурска општина на молбу Месног просветног одбора издвојила 10.000 круна, а да је један добротвор обећао да ће за ове циљеве после смрти завештати "око два фртаља земље“. ${ }^{21}$

Непосредно после Биндасовог апела русинској интелигенцији активности на пољу културно-просветног живота у Руском Крстуру отпочео је учитељ М. Поливка, а кад се он разболео, тај посао је преузео парох Михајло Мудри. Он је у писму од 11. марта 1919. године обавестио Биндаса о припремама за велику скупштину 16. марта на којој треба да се изабере просветни одбор. Наводи и да се у селу води акција прикупљања средстава и да ће се она пренети у главни фонд друштва, када се оно оснује. На скупштини је био изабран просветни одбор на челу са М. Мудрим. ${ }^{22}$

Ускоро после оснивања просветног одбора у Р. Крстуру такав одбор је основан и у Ђурђеву: на седници црквене општине 23. марта, уз присуство око 150 Русина, изабран је одбор од 8 чланова на челу са Ђ. Биндасом. Том приликом

\footnotetext{
${ }^{19}$ Варга, Д., Учителє-дзияции - "народни предняцฺи", 59-60.

${ }^{20}$ Исто, 60-61.

${ }^{21}$ Исто, 61.

22 Варга, Д., Початки нациионално-културного руху при Руснацуох Югославиї. 70-рочнйца Руского народного просвитного дружтва, Шветлосц, 4/1989, Нови Сад 1989, 514-515.
} 
основан је и фонд за издавање русинских новина: прикупљено је 1030 круна, а планирано је и прикупљање новца по кућама. Русински учитељи у Ђурђеву упочетку нису били укључени у ту акцију, мада је директор школе Михајло Љикар касније писао да су учитељи били носиоци културне делатности међу народом. ${ }^{23}$

Када је међу Русинима у Бачкој већ увелико покренута акција о оснивању РНПД, и када су у Р. Крстуру, Куцури и Ђурђеву изабрани месни просветни одбори с циљем да воде активности око оснивања друштва и прикупљања средстава за издавање русинских новина, Биндас је сматрао да се може прећи на другу фазу - да се организује скуп на ком ће представници Русина из појединих насеља у Краљевини СXC да оснују своје просветно друштво. Он је 31. марта упутио други апел „Бачко-сремској русинској интелигенцији“ у ком је изразио своју радост да је његов први апел наишао на леп одазив, а тамо где још није, треба мало више радити на томе, али не наводи на које русинске средине се то односи. Највероватније на Срем, јер нема података о томе да ли је међу Русинима у Срему било одазива на први апел Ђ. Биндаса, односно током прве фазе припрема за оснивање РНПД. Даље Биндас у апелу наводи да је куцнуо последњи час да се све оно што се речима и писмима оглашавало, коначно покаже на делу, и да интелигенција хоће и може да преузме на себе одговорност за националну будућност свог народа. Изгледа да се Биндас уплашио да одуговлачење са заказивањем оснивачке скупштине само отвара простор за распламсавање расправа о русинском књижевном језику, а да би то на крају могло да упропасти целу ствар. Зато, да уложени труд случајно ни би се изјаловио, Биндас је предложио да се за 14. мај у Новом Саду закаже „Народни русински просветни организациони састанак“. Замолио је све делегације да припреме правила друштва које ће се основати и нагласио да ће се на седници расправљати о уџбеницима, о наставном језику у русинским школама, о календару за 1920. годину, о издавању новина, о интернату за русинске ученике и о другим стварима. Наводи да ће скуп бити одобрен од власти и да ће бити јавни, а свој апел русинској интелигенцији завршио је речима „Поддунавски Русини оставте глубокий сон!". 24

Истог дана Биндас је обавестио J. Храниловића да је у договору са Крстурцима замолио крижевачког епископа да се корона - годишњи састанак свештеника овог деканата, одржи у Новом Саду 13. маја. ${ }^{25}$ Биндас је овај датум за корону предложио због тога што је 14. Мај већ предложио сазивање велике просветне скупштине русинске интелигенције из Бачке и Срема, јер је веровао да ће свештеници који дођу на корону доћи и на оснивачку скупштину просветног друштва. Искусни организатор морао је да мисли на све, јер у то време у Нови Сад није било лако стићи, како ће се видети из наредних редова, а осим тога то је био и приличан издатак за сваког појединца. Биндас ипак није желео да скупштина русинске интелигенције буде на терет Храниловићу и предложио му је да се она одржи у школи или на неком другом месту. Сматрао је такође да се свако може да

\footnotetext{
${ }^{23}$ Варга, Д., Початки национално-културного руху при Руснацох Югославиї, 515.

${ }^{24}$ Миз, Р., Гу "Хронӥки єдного часу" (1), 255-256.

${ }^{25}$ Исто, 256.
} 
се сам побрине за исхрану, али је замолио Храниловића да обезбеди ноћење по русинским кућама у граду за оне који дођу на скупштину. На крају је нагласио да и ако корона не би се одржала како је предложуо, скупштина русинске интелигенције ће се одржати 14. маја, јер се мора решити важна питања русинских школа. На крају је замолио Храниловића да провери да ли је тачно да је издата нова наредба према којој тамо где има више од 50\% српске деце настава у школи мора да буде на српском језику, као и да обезбеди дозволу за одржавање скупштине русинске интелигенције. Биндас само једно није могао да предвиди: да ли ће тога дана услови комуникације омогућити да на скупштину дођу не само Русини из Бачке него и они из Срема. ${ }^{26}$

На други Биндасов апел први се одазвао М. Поливка из Р. Крстура наводећи да су крстурски учитељи расправљали о позиву на састанак у Нови Сад, да су спремни да се укључе у оснивање просветног друштва и да делују у његовом раду, као и да су сви учитељи и учитељице заинтересоване да дођу на састанак. ${ }^{27}$

Изгледа да је Биндас после упућивања другог апела поново посетио Крстурце и Куцуране да би се с њима договорио о неким важним питањима које је требало решити пре саме скупштине, да различити ставови не би тамо изазвали непотребне расправе. Крстурски учитељи на челу са М. Поливком сматрали су да скупштина треба да се што пре одржи да би се летњи одмор искористио за припреме за нову школску годину. Крстурска интелигенција је била мало флексибилнија у избору будућег књижевног језика, али Куцурани су били доследни у своме и чврсто су стајали на позицији да за књижевни језик Русина у Краљевини СХС треба узети „малоруски језик“ односно карпаторусински језик. Биндас је морао да их смирује да њихов чврст став не изазове озбиљније неспоразуме са другима, који су имали другачије ставове. ${ }^{28}$

После тога Биндасу се из Куцуре 22. априла јавио Е. Губаш и наводио своје приватне проблеме а посебно је описао заоштравање односа између народа и куруских учитеља због тога што је на седници општинског одбора било изгласано да се учитељима не додели материјална помоћ како су предложиле школске власти. Због тога је цео учитељски збор одлучио да се учитељи повуку са свих јавних дужности и да пусте да народ ради све како сам зна. Губаш наводи да је дао оставку на место председника Месног просветног одбора и да је уместо њега на ту дужност изабран свештеник Владимир Сегеди. Своје велико огорчење Губаш је изразио речима да учитељи не могу да буду вође народу који не поштује своје људе него их само вређа. ${ }^{29}$ у следећем писму Губаш даје Биндасу неке практичне савете у вези одржавања скупштине: да од градског великог капетана на време треба обезбедити дозволу за одржавање скупштине, а такође га је замолио да јави за колико људи треба да се обезбеди ноћење у Новом Саду. ${ }^{30}$

\footnotetext{
${ }^{26}$ Миз, Р., Гу ”Хронӥки єдного часу” (1), 256-257.

${ }^{27}$ Варга, Д., Перши написал и злоІел руски школски кнїжки, 451.

${ }^{28}$ Варга, Д., Перии написал и злоІел руски школски кнїжки, 451.

${ }^{29}$ Варга, Д., Учителє-дзияции - "народни предняции", 62.

${ }^{30}$ Исто, 62.
} 
Биндас се нашао затечен чињеницом да је у тако важном тренутку за решавање русинског културно-просветног и националног питања настао сукоб између народа и учитеља у Куцури, јер не само да је одједном спласнуло одушевљење куцурске интелигенције, већ је постојала опасност да се народ потпуно окрене против ње. Зато је покушао да уради нешто тамо где је сматрао да има највише утицаја: да смири Е. Губаша, да му пружи подршку и мало му подигне морал. Изгледа да му је то успело, јер у следећем писму Губаш пише да, без обзира на то што је дао оставку на место председника Месног просветног одбора, ипак и даље подржава оснивање русинског просветног друштва. Такође је изразио своје задовољство да се није заборавило ни на Русине у Срему, али је упозорио да им треба помоћи да себи обезбеде документа да би могли да дођу на скупштину у Нови Сад. На крају обећава Биндасу да ће му помоћи у обезбеђивању ноћења за оне који ће доћи на скупштину, јер познаје Русине у граду. ${ }^{31}$

Није сасвим јасно када и где је донета одлука да се скупштина заказана за 14. мај не одржи тог дана. Основни разлог за то биле су тешке прилике у комуникацијама. Недељу дана пре одржавања скупштине, 6. маја Ђура Бесермињи, гркокатолички парох из Шида, обавестио је Биндаса да, ако из неких непредвидљивих разлога не буде спречен, планира да допутује у Нови Сад бродом заједно са беркасовачким учитељем Осифом Губашем, Спиридоном Петрановићем, парохом у Петровцима, и свештеником Михајлом Хирјоватим, парохом у Рајевом Селу. Ако ипак случајно буде спречен, на скупштини ће га заступати С. Петрановић. Из тог писма се види да Русини у Срему 6. маја још нису знали да се скупштина неће одржати. Скупштина је била одложена због тога што су делегати из Крстура и Куцуре планирали да допутују у Нови Сад возом, а возови нису саобраћали. $^{32}$

Касније је одлучено да се скупштина одржи у Новом Саду 2. јула 1919. године. Кад је датум већ био утврђен, крстурски парох М. Мудри је 27. маја писао Биндасу да треба „алармирати људе“ да се припремају за скупштину, али је с друге стране био скептичан да ли ће се скупштина одржати у ситуацији када јавни превоз не функционише. Даље обавештава Биндаса да су у Р. Крстуру припремили правила за деловање будућег просветног друштва и да су их послали у Куцуру, а на крају наводи да због великих води није могуће да се путује ни колима. ${ }^{33}$ Како се приближавало време одржавања скупштине, тако су Биндасу све чешће стизала писма од русинских првака. Емилијан Губаш га је обавестио да ће 12. јуна бити у Н. Саду и да би волео да се нађе с њим. Спомиње да га је болела нога и да тешко хода, тако да у припремању скупштине неће моћи много да помогне. Предложио је да се о одржавању скупштине дају огласи и у српским новинама, јер је сматрао да Русини мало читају словачке новине. Пошто је схватио да су у Срему русински прваци позвали на скупштину све заинтересоване, а не само изабране делегате, како је првобитно било предвиђено, сматрао је да и у Бачкој треба да се позову сви

\footnotetext{
${ }^{31}$ Варга, Д., Учителє-дзияции - "народни предняции", 62.

${ }^{32}$ Цап, М., Прилоги за историю рускей култури у Югославиї.Шветлосц, 4/1980, Нови Сад 1980, 448.

${ }^{33}$ Цап, М., Прилоги за историю рускей култури у Югославиї, 449.
} 
заинтересовани, и да се не треба плашити да ће доћи много људи, јер су транспортне прилике биле тешке, а поред тога, такав пут је приличан издатак. ${ }^{34}$ Из овога се види да је Губаш добро познавао менталитет Русина и да је знао да многи нису спремни да дају новац тамо где не морају, односно да осећање колективне одговорности за општенародно добро још није било развијено.

После тога Биндасу се писмом јавио М. Поливка из Р. Крстура у ком је изјавио да цени његов рад који је започео у интересу русинског народа и исказао је своје жаљење да због болести није могао да више помогне у том тешком послу. Наводи да у Крстуру има доста заинтересованих који планирају да оду на скупштину, али се помало прибојавао да ли ће скупштина бити одржана због транспортних прилика. Сматрао је да седница свакако треба да се одржи да би се што пре решило питање русинских школа, јер није решено ни питање уџбеника који ће се од јесени користити у русинским школи, нити на ком језику ће се у њима изводити настава. Он је сматрао да ако се то ускоро не реши, у септембру ће поново почети настава на разним језицима и из различитих књига, а то ће бити на штету просвете. Зато је наглашавао да састанак треба да се што пре одржи, па макар и на другом месту, ако то није могуће у Новом Саду.

Што се пак тиче наставног језика у русинским школама, Поливка је видео три могућности: а) да се уведе украјински или руски књижевни језик; б) да се узме овдашњи народни русински језик, с тим да се он допуњује речима из украјинског језика; в) да се узме овдашњи народни русински језик и да се допуњује речима неког од јужнословенских језика. Он је сматрао да ове могућности треба предочити ширем кругу људи, испитати какав је став народа о овом питању и о свему обавестити Биндаса. Оснивање просветног друштва Поливка је видео као формирање законитог представништва Русина на културном и просветном пољу, ${ }^{35}$ и управо због тога је стално указивао да је неопходно да се због решавања школског питања односно питања наставног језика у русинским школама што пре одржи оснивачка скупштина просветног друштва. Он је био против тога да одлуку о наставном и књижевном језику доноси ужи круг људи односно стручњака, већ је сматрао да ово питање треба изнети пред народ да би он донео одлуку о томе.

Проблеми због којих није одржана скупштина 14. маја претили су да се неће одржати ни поново заказана скупштина за 2. јул, јер возови још увек нису саобраћали, а ни другог јавног превоза није било. И док је Ђ. Биндас улагао много напора да што боље припреми заказану скупштину, крстурски парох М. Мудри је 1. јуна у кратком писму навео да би „најбоље било да се у таквим временима мирује“, мада је био свестан да започети посао треба да се доведе до краја. ${ }^{36}$ Међутим, већ у следећем писму, које није датирано, указивао је да није спреман да се ухвати у коштац са транспортним приликама па је предлагао Биндасу да се, ако представници Русина из Бачке не буду могли доћи у Нови Сад, састанак одржи у Р. Крстуру или у Куцури, где ће се састати макар и ужи круг људи, да се друштво

\footnotetext{
${ }^{34}$ Варга, Д., Учителє-дзияции - "народни предняции", 63.

${ }^{35}$ Цап, М., Прилоги за историю рускей култури у Югославиї, 450-452.

${ }^{36}$ Цап, М., Прилоги за историю рускей култури у Югославиї, 450.
} 
оснује и да се донесу неопходне одлуке, а касније да се и други прикључе. Мудри је Биндасу дао да знања да Крстурци желе да њихов народни језик постане књижевни, који би се допуњавао речима из украјинског и јужнословенског језика. Такође је указивао да треба донети одлуку које књиге ће се користити у русинским школама док се не штампају нове русинске књиге. Иако је уверавао Биндаса да се он спрема да дође у Нови Сад на скупштину као и сва интелигенција, и још 7-8 људи из народа, ипак је писмо завршио веома песимистичним предвиђањем: „Мислим да и ти знаш да од тога неће бити ништа, јер је велика криза“. ${ }^{37}$ После тога М. Мудри је у писму Биндасу 26. јуна поново изнео своје колебање: уверавао га је да су сви делегати из Р. Крстура спремни да дођу, али да се плаше да возови неће саобраћати. Због тог је предложио да се састанак одржи у Р. Крстуру и да се одмах одреди датум. На крају саопштава Биндасу да је припремио реферат о језику и моли га да он припреми реферат о потреби оснивања просветног друштва. ${ }^{38}$

Изгледа да су после тог писма М. Мудрог Биндасу и из Р. Крстура и из Куцуре јавили да возови 2. јула сигурно неће саобраћати, ${ }^{39}$ што га је јако потресло, jep се уверио да његов велики труд и трошкове око организовања оснивачке скупштине његове колеге свештеници и интелигенција недовољно цене и да нико није спреман да нешто жртвује за општи интерес. Одмах је одговорио М. Мудром описујући целу ситуацију. Наводи да је у четвртак био у Новом Саду и да је све урадио да се скупштина одржи, а када се вратио кући, сазнао је да су му из Крстура и из Куцуре телефоном јавили да они не могу доћи у Нови Сад јер возови неће саобраћати. У петак му је то исто јавио телефоном нотар Владислав Пољак и предложио да се састанак одржи у Р. Крстуру или у Куцури. На крају су из Р. Крстура поново јавили да ће доћи у Нови Сад на скупштину. После толико и таквих информација Биндас стварно није могао да схвати шта се дешава и шта треба да почне, па је М. Мудром одговорио: „Не могу да вам опишем колико сам огорчен сада кад сам већ у души видео готов наш народни почетак, и да ће ме дуго душа болети над рушевинама тог тешког почетка“. Биндас је прихватао чињеницу да није лако да се путује када возови не саобраћају, али је додао: „Па зар ја возом путујем у Нови Сад или другде? Зар мене није коштао пут у свакој прилици 100-150 и више круна? Видео сам јуче да људи колима лако долазе из Крстура. Ваљда нисте очекивали да вам и то обезбедим?!“ Ипак, Биндас је овакав лежеран и неодговоран однос колега и сарадника према одржавању оснивачке скупштине русинског просветног друштва доживљавао не само као лични неуспех, већ и као „велику бламажу пред туђим светом“, јер је у јавности све већ било обнародовано, и сматрао је да би се русинска интелигенција стварно требала стидети пред властитим народом, јер је неспособна да нешто уради. Он је већ предвиђао како ће на крају људи из народа самоуверено говорити: „Нисам ли рекао да наша господа ништа неће урадити, она види само свој интерес?!“

\footnotetext{
${ }^{37}$ Цап, М., Прилоги за историю рускей култури у Югославиї, 453.

${ }^{38}$ Цап, М., Прилоги за историю рускей култури у Югославиї, 453-454.

${ }^{39}$ Варга, Д., Початки национално-културного руху при Русначох Югославиї, 517.
} 
Биндас је знао да се решавање других питања може одложити, ако оснивачка скупштина не би се одмах одржала, али би остало нерешено школско питање, а оно је, по њему, било у оном тренутку најважније. Плашио се да ће, ако се скупштина не одржи, све остати по старом: Русини у Бачкој ће радити по своме, они у Срему по своме. Ако би се то догодило, Русинима у Бачкој би и даље претила србизација, а онима у Срему - кроатизација. ${ }^{40}$

Из дана у дан ствари око одржавања оснивачке скупштине у Новом Саду су се мењале. Оно што је данас било договорено и јасно, већ сутрадан би постало несигурно или немогуће. На Биндасово писмо М. Мудри 29. јуна одговара доста опширно, покушавајући да се мало оправда, свестан да му је задао доста мука када су му јавили да делегати из Р. Крстура и Куцуре неће доћи на оснивачку скупштину јер возови не саобраћају. Михајло Мудри у писму обавештава Биндаса да су се, на сву срећу, ствари промениле, јер је у Р. Крстуру „енергичан биров“ Сопка Иљко у ноћи од суботе на недељу обилазио људе у селу и на крају обезбедио кола за пут. Планира се да на скупштину у Нови Сад из Крстура дођу делегати са 6-8 кола. Још је требало да нотар Владислав Пољак јави Куцуранима да Крстурци одлазе у Нови Сад колима, да се и они тако спремају. Мудри је обећао да ће о свему обавестити гркокатоличког пароха у Ст. Врбасу Александра Абодића и адвоката Михајла Хајнала, а Биндаса је замолио да обавести Русине у Срему. На крају наводи да у свом реферату спремљеном за оснивачку скупштину предлаже да живи народни говор, којим говоре овдашњи Русини, постане њихов књижевни језик, јер ако би сде одлучило другачије - то би био туђи језик, а не властити. Мудри сматра да је то једини пут да овдашњи Русини остану Русини. ${ }^{41}$

После одржане скупштине РНПД 2. јула 1919. године Ђ. Биндас је примио још два писма у вези скупштине и оснивања просветног друштва од Ђуре Љикара, директора школе у Ђурђеву. У првом писму, писаном 1. јула, Љикар га обавештава да, иако се припремао, због „непредвидљиве запреке“ неће доћи на скупштину, али изјављује да ће својом душом бити присутан и да ће неуморно радити у корист русинске просвете. ${ }^{42}$ Садржај другог писма је сличан: Љикар пише Биндасу да ће му касније рећи зашто није дошао на скупштину и моли га да на скупштини прочита његово писмо, а на крају поново обећава да ће у просветном друштву радити и више од осталих учитеља. ${ }^{43}$ Ипак, време ће показати, да су то била већа обећања од искрене спремности да ради у корист русинске просвете.

Коначно, после дугих припрема, уз много неизвесности, различитих ставова о будућем књижевном и наставном русинском језику, 2. јула 1919. године у згради Новосадског магистрата, уз присуство око 150 представника Русина из Бачке и Срема, одржана је оснивачка скупштина Русинског народног просветног друштва. Скупштину је поздравним говором отворио Ђура Биндас и предложио је за председавајућег скупштине Јован Храниловића. После избора радног

\footnotetext{
${ }^{40}$ Варга, Д., Початки национално-културного руху при Руснацох Югославиї, 528.

${ }^{41}$ Цап, М., Прилоги за историю рускей култури у Югославиї, 454-456.

${ }^{42}$ Исто, 456.

${ }^{43}$ Исто, 457.
} 
председништва Ђ. Биндас је прочитао реферат о потреби оснивања русинског просветног друштва, ${ }^{44}$ а М. Мудри је прочитао реферат о русинском књижевном језику, образлажући зашто би Русини у Краљевини СХС требали да за свој књижевни језик узму свој народни језик. ${ }^{45}$ На скупштини је донета одлука о оснивању Русинског народног просветног друштва, а његов циљ ће бити, како стоји у Правилима РНПД: ${ }^{46}$ „Да издаје и шири на популарном русинском језику написане књиге и брошуре побожног, поучног и забавног садржаја и да издаје русинске народне новине“ (Правила: 1). За председника Друштва изабран је М. Мудри, а за подпредседнике Ђура Биндас и Емилијан Губаш. На скупштини је, на предлог М. Мудрог, скоро једногласно донета одлука да се за књижевни језик Русина у Краљевини СГС прихвати њихов народни језик (Записник: 8).

Тако су Русини на Оснивачкој скупштини у Новом Саду 2. јула 1919. године основали своје прво културно-просветно друштво на овим просторима, које је у периоду између два светска рата одиграло веома значајну улогу у њиховом културно-просветном и националном животу у Краљевини СХС/Југославији.

\footnotetext{
44 Биндас, Ю. (1921). О пребудзеню бачвано-сримских Русинох. Руски календар 1921, 2-6. Руски Керестур: Руске народне просвитне дружтво.

${ }^{45}$ Мудри, М. (1921). О язику за южно-славянску руску писменоси. Руски календар 1921. 35-42. Руски Керестур: Руске народне просвитне дружтво

46 Правила РНПД донета на оснивачкој скупштини РНПД 2. јула 1919. године одобрена су у Министарству унутрашњих дела у Београду 10. јуна 1920. године.
} 


\section{Извори и литература:}

Аноним, Пред 50 роками почали виходзии перши новини за югославянских Русинох. Нова думка, 9, Вуковар 1975, 75-82.

Biljnja, V., Rusini u Vojvodini (Prilog proučavanju istorije Rusina Vojvodine 1918

- 1945), Novi Sad 1987.

Биндас, Д., Народна штатистика бачко-сримских Русинох 1921. року, Руски календар 1923, Руски Керестур 1923, 130-131.

Ванат, І., Нариси новітньої історії украӥнців Східної Словаччини I (1918 -1938) Пряшів, Словацьке педагогічне видавництво в Братіславі, Відділ української літературі в Пряшеві 1990.

Варга, Д., Учителє-дзияии - "народни предняии". Шветлосц, 1/1988, Нови Сад 1988а, 39-63.

Варга, Д., Перии написал и злоел руски школски кнїжки. Стодвачеирочнїиа нарадзеня Михаила Поливки (1868-1988). Шветлосц, 4/1988, Нови Сад 1988б, 435-464.

Варга, Д., Початки национално-културного руху при Русначох Югославиї. 70-рочнӥиа Руского народного просвитного дружтва, Шветлосц, 4/1989, Нови Сад 1989, 509-540.

Gaćeša, N., Rusini između dva svetska rata, Godišnjak Društva istoričara Vojvodine, 1977, Novi Sad 1977, 275-308.

Гнатюк, В., Словащи чи Руснаци? Етнографични материяли з Угорскей Руси, т. V, Нови Сад 1988, 127-201.

Записник I-го руского народного собрания отриманого 2./VII 1919. Року у Новим-Саду, Руски календар, Руски Керестур 1921, 6-8.

Костельник, Г., Liber тетоrabilium грекокатолӥикей парохиї бачкерестурскей. Нови Сад 1998.

Миз, Р., Гу "Хронїки єдного часу" (1). Шветлосц, 3, Нови Сад 1969, 253-266.

Мушинка, М., Зв'язки володимира Гнатюка з югославськими русинами. Шветлосц 3/1971, Нови Сад 1971, 221-239.

[Няради, Д.]. Правди католичкей в ъри. Жовква 1912.

Няради, Д., Книжочка для членовънабожного союза 'Живого рожаниа' въ епархиі крижеваикой, Загреб 1917.

Pekić, P., Povjest oslobodjenja Vojvodine, Subotica 1931.

Правила Руского народного просв Бтного друштва, Руски календар, Руски Керестур 1921, 8 12.

Цап, М., Прилоги за историю рускей култури у Югославиї.Шветлосц, 4/1980, Нови Сад 1980, 444-464. 


\title{
PREPARATION FOR THE ESTABLISHMENT OF A RUTHENIAN CULTURAL AND EDUCATIONAL NATIONAL SOCIETY
}

\begin{abstract}
Summary
Until 1918, Ruthenians in the Southern Hungary did not have their cultural, educational and national organizations or institutions. An attempt to start with publishing of the calendar for 1913 in the native language of the Ruthenians in Bačka and Srem was a realistic way to develop their cultural-educational and national life, but only after the collapse of the Austro-Hungarian Empire and the foundation of the Kingdom of SCS, which created favorable conditions to move in that direction. Preparations for the establishment of the first Ruthenian cultural-educational societies in this region revealed dilemmas about accepting the Ruthenian language, and problems of choice of the language taught at schools, which was related to the provision of textbooks for the Ruthenian schools. Partitions and a lack of willingness on the part of activities of the Ruthenian intelligence and objectively unfavorable postwar conditions were very strong obstacles to very agile Đura Bindas to start with the implementation of plans to initiate an educational, cultural and national revival of the Ruthenians. Finally, on 02 July 1919, the Constitutional Assembly established Ruthenian National Educational Society in Novi Sad in order to preserve the Ruthenian ethnicity, expand and develop cultural and educational life, and represent the interests of the Ruthenians in the country.
\end{abstract}

Keywords: Russians in the Kingdom of SCS / Yugoslavia, Ruthenian National Educational Society, Ruthenian literary language, Đura Bindas, Mihajlo Mudri, Dionysus Njaradi. 